\title{
Interventions to enhance teamwork in healthcare professionals: a mini review
}

\author{
Abstract \\ Introduction: Research has shown that patients' perception of the care they received \\ is considerably increased when members of the healthcare team work together. \\ Aim: Which are the interventions most used to enhance teamwork among healthcare \\ professionals? \\ Discussion: A literature search was conducted in databases such as; DynaMed, \\ EBSCO HOST, Journal of the American Medical Association (JAMA), Nature- \\ International weekly journal of science and Wolters Kluwer Health, with the keywords \\ from Medical Subject Heading (MESH) "Healthcare personnel", "Healthcare teams" \\ and "Intervention study".
}

Conclusion: It is concluded that teamwork training is essential in order to provide high-quality and cost-effective care.
Volume 5 Issue 2 - 2018

\author{
Higinio Fernández-Sánchez, María del \\ Carmen Santes-Bastian, Erika Mayte Del \\ Ángel-Salazar, Nazaria Martínez-Díaz, David \\ Hernández-Zepeta, Mireya Cruz-Ruiz \\ Facultad de Enfermería, Universidad Veracruzana, Mexico
}

Correspondence: Higinio Fernández-Sánchez, Facultad de Enfermería, Universidad Veracruzana, Mexico, Tel (782) 8282024, Email hifernandez@uv.mx

Received: February 16, 2018 | Published: March 28, 2018

Keywords: intervention study, healthcare team, review

\section{Introduction}

Healthcare is a complex occupation that one professional can't be held liable for it, but by a multidisciplinary team where each is responsible of carrying-out certain tasks depending on their profession, but they all have the common goal of improving the patients' wellbeing. ${ }^{1}$ Research has shown that patients' perception of the care they received is considerably increased when members of the healthcare team work together. ${ }^{1,2}$ Furthermore, interpersonal and communication skills in a team helps improve the job satisfaction among workers. ${ }^{2}$ Teamwork has been defined as "a positive work relationship among nurses or other personnel, but also as interprofessional relations, peer cohesion, social support, collaborative decision-making, and the amount of clinical support". ${ }^{3}$ Researchers have found that teamwork and collaboration can help improve care processes while reducing the number of medical errors and increasing patient safety. ${ }^{4,5}$

\section{Discussion}

\section{Eligibility criteria}

A review was conducted among the scientific literature related to the interventions to enhance teamwork in healthcare professionals. The main question for this integrated review was "Which are the interventions most used to enhance teamwork among healthcare professionals". To search and choose the studies, five databases were consulted: DynaMed, EBSCO HOST, Journal of the American Medical Association (JAMA), Nature-International weekly journal of science and Wolters Kluwer Health, with the keywords from Medical Subject Heading (MESH) ${ }^{6}$ "Healthcare personnel", "Healthcare teams" and "Intervention study", conducted between June and July 2017. Studies published in English and Spanish were included with abstracts and texts in full-length accessible.

\section{Selection of studies}

All studies discussing interventions to enhance teamwork in nursing professionals were included, regardless of the type of study.

\section{Process for data collection}

Firstly, members of the research team reviewed, analyzed and summarized the data from the studies individually, afterwards, the data was reviewed by another researcher of the team.

\section{Characteristics of selected studies}

The investigations contemplated, were the studies to enhance teamwork in healthcare professional published in the languages mentioned above.

\section{Conclusion}

After the literature search, eight studies were identified and analyzed in full, four articles were selected, they are described in Table 1. The Level of Evidence was considered according to the "Evidencebased nursing care guidelines: Medical-surgical interventions".?

Healthcare is a multifaceted entity that requires a group of multiple, talented experts, like nurses, physicians and psychologists to provide high-quality care. It has been shown that teamwork training is essential in order to provide high-quality and cost-effective care. The authors of this integrative review, conclude that teamwork can be enhanced when components such as interpersonal and communication skills are developed, while improving team behaviors that will help lower errors in the clinical setting. 
Table I Summary findings of selected studies

\begin{tabular}{|c|c|c|c|c|c|}
\hline Reference & Aim & Method & $\begin{array}{l}\text { Active ingredients } \\
\text { and components }\end{array}$ & Results & $\begin{array}{l}\text { Level of } \\
\text { evidence }\end{array}$ \\
\hline $\begin{array}{l}\text { P McCulloch, } \\
\text { J Rathbone, } \\
\text { K Catchpole }\end{array}$ & $\begin{array}{l}\text { To capture all studies } \\
\text { of interventions with } \\
\text { healthcare workers and } \\
\text { healthcare teams designed } \\
\text { to facilitate teamwork and } \\
\text { communication skills. }\end{array}$ & $\begin{array}{l}\text { A systematic Literature review } \\
\text { of Randomized and non- } \\
\text { randomized Controlled Trials. }\end{array}$ & $\begin{array}{l}8 \text { studies: Non- } \\
\text { technical skills } \\
\text { or teamwork } \\
\text { performance. } 7 \\
\text { studies: Safety cultura } \\
8 \text { studies: Changes in } \\
\text { technical performance } \\
\text { or error 3: Changes in } \\
\text { clinical outcomes }\end{array}$ & $\begin{array}{l}6 \text { of } 8 \text { studies found a positive } \\
\text { effect on teamwork behavior. } 5 \\
\text { of } 8 \text { studies found improvement } \\
\text { for technical performance. Half of } \\
\text { studies measuring safety culture } \\
\text { found benefits from teamwork } \\
\text { training. }\end{array}$ & Level I \\
\hline $\begin{array}{l}\text { Kalisch BJ, } \\
\text { Arberdol M, } \\
\text { McLaughlin } \\
\text { M, et al. }{ }^{9}\end{array}$ & $\begin{array}{l}\text { To test the use of virtual } \\
\text { simulation to improve } \\
\text { teamwork among nursing } \\
\text { staff }\end{array}$ & $\begin{array}{l}\text { A quasi-experimental design } \\
\text { using a virtual simulation } \\
\text { environment where the } \\
\text { participants used an avatar. } \\
\text { Doses: I session of I hour. Pre } \\
\text { and Post test measurements. }\end{array}$ & $\begin{array}{l}\text { Teamwork training: } \\
\text { virtual simulation; } \\
\text { knowledge about } \\
\text { teamwork }\end{array}$ & $\begin{array}{l}\text { Teamwork scores improved } \\
(p<.012) \text {. Teamwork subscales } \\
\text { (trust, team orientation and } \\
\text { backup) had a large improvement. }\end{array}$ & Level III \\
\hline $\begin{array}{l}\text { Thomas EJ, } \\
\text { Taggart B, } \\
\text { Crandell S, } \\
\text { et al. }{ }^{10}\end{array}$ & $\begin{array}{l}\text { To ass a team training and } \\
\text { human error curriculum } \\
\text { to the Neonatal } \\
\text { Resuscitation Program } \\
\text { and measure its effect on } \\
\text { teamwork. }\end{array}$ & $\begin{array}{l}\text { A randomized trial. } 18 \\
\text { participants were assigned to } \\
\text { the NRP with team training } \\
\text { and } 22 \text { assigned to standard } \\
\text { NRP. }\end{array}$ & $\begin{array}{l}\text { Teamwork behaviors: } \\
\text { Inquiry; Information } \\
\text { sharing;Assentation; } \\
\text { Evaluation of } \\
\text { plans;Workload } \\
\text { management;Vigilance }\end{array}$ & $\begin{array}{l}\text { Participants in the NRP with } \\
\text { team training experienced } \\
\text { more frequent team behaviors } \\
\text { compared to the control } \\
\text { group ( } \mathrm{p} \text {-values }<0.008 \text { for } \\
\text { all comparisons). } 100 \% \text { of } \\
\text { participants in the NRP } \\
\text { with team training practiced } \\
\text { vigilance throughout the entire } \\
\text { intervention and } 88 \% \text { practiced } \\
\text { workload management. }\end{array}$ & Level II \\
\hline $\begin{array}{l}\text { Morey JC, } \\
\text { Simon R, Jay } \\
\text { GD, et al." }\end{array}$ & $\begin{array}{l}\text { To evaluate the } \\
\text { effectiveness of training } \\
\text { and institutionalizing } \\
\text { teamwork behaviors, } \\
\text { drawn from aviation crew } \\
\text { resource management } \\
\text { (CRM) programs, on } \\
\text { emergency department } \\
\text { (ED) staff organized into } \\
\text { caregiver teams. }\end{array}$ & $\begin{array}{l}\text { Quasi-experimental design. } \\
\text { I pretest and } 2 \text { posttests. } \\
\text { Duration of intervention of } 6 \\
\text { months. }\end{array}$ & $\begin{array}{l}\text { Teamwork } \\
\text { improvement; Team } \\
\text { behavior; Emergency } \\
\text { department } \\
\text { performance; } \\
\text { Attitudes and } \\
\text { opinions }\end{array}$ & $\begin{array}{l}\text { Improvement in the quality } \\
\text { of team behaviors was shown } \\
\text { between the intervention and } \\
\text { control group }(p=.012) \text {. In } \\
\text { the intervention group: The } \\
\text { subjective work overload wasn't } \\
\text { affected }(p=.668)\end{array}$ & Level III \\
\hline
\end{tabular}

\section{Acknowledgements}

None.

\section{Conflict of interest}

The author declares that there is no conflict of interests.

\section{References}

1. O Daniel, Rosenstein. Professional communication and team collaboration. In: Hughes RG, editor. Patient safety and quality: an evidence-based handbook for nurses. Rockville (MD): Agency for Healthcare Research and Quality (US). Chapter 33. 2008.

2. Global Resource Center. Why is teamwork in health care important? 2018.

3. Schalk DM, Bijl MLP, Halfens RJG, et al. Interventions aimed at improving the nursing work environment: a systematic review. Implement Sci. 2010;5(34):2-11.

4. Xu JH. Toolbox of teaching strategies in nurse education. Chin Nurs Res. 2016;3(2):54-57.
5. Moreno-Fernández MT. Análisis del trabajo en equipo entre enfermeras y auxiliaries de enfermería, según los distintos modelos de organización de enfermería. Universidad Pública de Navarra. 2015.

6. Medical Subject Headings. [MeSH subject heading scope note]. 2018.

7. Ackley BJ, Swan BA, Ladwig G, et al. Evidence-based nursing care guidelines: Medical-surgical interventions. St. Louis MO: Mosby Elsevier; 2008 .

8. McCulloch $\mathrm{P}$, Rathbone $\mathrm{J}$, Catchpole $\mathrm{K}$. Interventions to improve teamwork and communications among healthcare staff. Brit $J$ Surg. 2011;98(4):469-479.

9. Kalisch BJ, Aebersold M, McLaughlin M, et al. An intervention to improve nursing teamwork using virtual simulation. West $J$ Nurs Res. 2015;37(2):164-179.

10. Thomas EJ, Taggart B, Crandell S, et al. Teaching teamwork during the neonatal program: a randomized trial. J Perinatol. 2007;27(7):409-414.

11. Morey JC, Simon R, Jay GD, et al. Error reduction and performance improvement in the emergency department though formal teamwork training: evaluation results of the MedTeams Project. Heal Ser Res. 2002;37(6):1553-1581. 